\title{
PENGARUH SIKLUS HIDUP DAN UKURAN PERUSAHAAN TERHADAP EARNING MANAGEMENT PADA PERUSAHAAN MANUFAKTUR YANG TERDAFTAR DI BURSA EFEK INDONESIA
}

\author{
Endang Kusumawati \\ Ari Dewi Cahyati \\ Dosen Jurusan Akuntansi Fakultas Ekonomi Universitas Islam Bekasi \\ Email: arde_ta@yahoo.com
}

Abstract

The study goal was to determine whether there is influence of the life cycle and firm size on earnings management in companies listed on the Stock Exchange Indonesia. Data tehnique collection is done by purposive sampling. The data used in this study is secondary data, engineering data collection is done by purposive sampling. The total sample of 78 manufacturing companies. The results showed that the life cycle variables significant positive effect on earnings management practices while the firm size variable is not significant effect on earnings management practices. In general it can be concluded that the only variable that has a life cycle just significant positive effect on earnings management. Subsequent researchers expected to add other factors influence earnings management as another independent variable, because it is possible that other factors not included in this study influence the practice of earnings management.

Kayword: life cycle, the size of company, earning management 
Abstrak

Tujuan Penelitian adalah untuk mengetahui apakah ada pengaruh siklus hidup dan ukuran perusahaan terhadap manajemen laba pada perusahaan manufaktur yang terdaftar di Bursa Efek Indonesia.Teknik pengumpulan data dilakukan dengan purposive sampling. Data yang digunakan dalam penelitian ini adalah data sekunder, teknik pengumpulan data dilakukan dengan purposive sampling. Total sampel 78 perusahaan manufaktur. Hasil penelitian menunjukkan bahwa variabel siklus hidup berpengaruh positif signifikan terhadap praktik manajemen laba sedangkan variabel ukuran perusahaan tidak berpengaruh signifikan terhadap praktik manajemen laba. Secara umum dapat disimpulkan bahwa hanya variabel siklus hidup saja yang memiliki pengaruh positif signifikan terhadap earning management. Peneliti berikutnya diharapkan menambah faktor pengaruh earning management lainnya sebagai variabel independen lain, karena sangat dimungkinkan faktor lain yang tidak dimasukkan dalam penelitian ini berpengaruh terhadap praktik earning management.

Kata kunci: siklus hidup, ukuran perusahaan, dan earning manajemen

\section{PENDAHULUAN}

Laporan keuangan merupakan sarana informasi bagi para pihak pemakai laporan keuangan, baik pihak eksternal maupun internal perusahaan. Menurut PSAK 2012 No.1 paragraf 05 tujuan umum laporan keuangan adalah memberikan informasi tentang posisi keuangan, kinerja dan arus kas perusahaan yang bermanfaat bagi kalangan pengguna laporan keuangan dalam rangka membuat keputusan-keputusan ekonomi serta menunjukkan pertanggungjawaban manajemen atas pengguna sumber-sumber daya yang dipercayakan kepada mereka.

Dalam penyusunan laporan keuangan dasar akrual digunakan untuk menyusun neraca, laporan rugi laba dan perubahan ekuitas. Dasar akrual dipilih karena lebih adil dan rasional dalam mencerminkan kondisi keuangan perusahaan secara riil, tetapi penggunaan dasar akrual memberi keleluasaan kepada pihak manajemen dalam memilih kebijakan akuntansi selama tidak menyimpang dari aturan Standar Akuntansi Keuangan yang berlaku, kebijakan akuntansi yang secara sengaja dipilih oleh manajamen untuk tujuan tertentu dan mengarah pada praktik earning management.

Earning management (manajemen laba) adalah potensi penggunaan manajemen akrual dengan tujuan memperoleh keuntungan pribadi. (Riahi \& Belkaoui, 2007:201), menurut Schipper (1989) yang dikutip oleh Shita (2011:4), earning management didefinisikan sebagai intervensi tujuan dalam proses pelaporan keuangan untuk memperoleh beberapa keuntungan pribadi. Davidson, dkk. (1987) dalam Shita (2011:4), menyatakan Earning management sebagai suatu proses pengambilan 
langkah-langkah yang disengaja dalam batasan prinsip akuntansi yang berterima umum untuk memperoleh laporan laba sesuai tingkatan yang diinginkan.

Para akademisi beragumen earning management bukan merupakan suatu kecurangan karena aktivitas rekayasa manajemen ini merupakan dampak dari prinsip akuntansi yang berterima umum yang menyediakan beragam metode dan prosedur yang bebas dipilih dan dipergunakan sesuai dengan keinginan dan tujuan perusahaan. Manajer dapat mengatur nilai perusahaan dengan memilih dan mengubah metodemetode yang ada karena mengubah metode yang dipakai berarti mengubah nilai seperti yang dikehendaki (Sulistyanto, 2008 dalam Shita, 2011:4). Walaupun earning management bukan sebuah kecurangan namun seringkali earning management menyebabkan informasi yang dihasilkan tidak mencerminkan keadaan perusahaan yang sebenarnya atau hanya mengutamakan kepentingan pihak tertentu saja sehingga menurunkan kualitas laporan keuangan dan menurunkan akurasi keputusan yang dihasilkan dengan dasar informasi tersebut. Banyak faktor yang mempengaruhi terjadinya earning management pada perusahaan diantaranya good corporate governance, Ukuran dewan komisaris, proporsi dewan komisaris independen, komite audit, reputasi Auditor, ukuran perusahaan, dan pertumbuhan perusahaan.

Penelitian sebelumnya dilakukan oleh Anggraini (2012) yang meneliti mengenai pengaruh siklus hidup perusahaan dan pengaruh ukuran perusahaan terhadap earning management. Hasil penelitian tersebut menjelaskan bahwa ukuran perusahaan memiliki pengaruh negatif secara signifikan terhadap earning management dan siklus hidup tidak berpengaruh signifikan terhadap earning management. Penelitian selanjutnya dilakukan oleh Veronika dan Utama (2005) dan Nuryaman (2008) dalam Shita (2011: 68) yang meneliti mengenai pengaruh struktur kepemilikian, ukuran perusahaan, dan praktik Corporate Governance terhadap earning management, menyimpulkan bahwa ukuran perusahaan memiliki pengaruh negatif signifikan terhadap Earning management.

Penelitian ini merupakan replikasi dari penelitian yang dilakukan oleh Angraini (2012) yang berjudul pengaruh siklus hidup perusahaan dan pengaruh ukuran perusahaan terhadap earning management. Perbedaan penelitian ini dengan penelitian sebelumnya adalah cara pengukuran variabel siklus hidup penelitian sebelumnya menggunakan rasio pembayaran pertahun, persentase penjualan, dan umur perusahaan sedangkan, penelitian ini menggunakan metode arus kas untuk mengklasifikasi tahap siklus hidup.

Berdasarkan latar belakang yang telah di uraikan tersebut, penulis tertarik untuk menyusun skripsi dengan judul 'Pengaruh Siklus Hidup dan Ukuran Perusahaan terhadap Earning Management pada Perusahaan Manufaktur yang Terdaftar di Bursa Efek Indonesia". Rumusan Masalah: (1) Apakah siklus hidup perusahaan mempengaruhi manajemen laba, (2) Apakah ukuran perusahaan mempengaruhi manajemen laba? Tujuan Penelitian: Tujuan Penelitian adalah untuk mengetahui 
apakah ada pengaruh siklus hidup dan ukuran perusahaan terhadap earning management pada perusahaan manufaktur yang terdaftar di Bursa Efek Indonesia.

\section{TINJAUAN PUSTAKA DAN PENGEMBANGAN HIPOTESIS}

\section{Tahapan Siklus Hidup Perusahaan}

Kreitner dan Kinicki $(1998,578)$ sebagaimana dikutip oleh Juniarti dan Limanjaya (2005) dalam Erviana (2012:21) mengungkapkan teori siklus hidup perusahaan sebagai berikut: "Like the people who make up organizations,organizations them selves go through life cycle. Organizations are born and, barring early decline, eentually grow and mature, if decline is not reversed the organizations dies."

Teori siklus hidup perusahaan ini mengungkapkan bahwa perusahaan melewati fase-fase tertentu dalam perjalanannya. Sama halnya seperti manusia, perusahaan juga diawali dengan kelahiran (pendirian), kemudian tumbuh dan matang seperti ibaratnya manusia dewasa, dan hingga akhirnya mati. Setiap tahapan yang dilewati perusahaan tersebut memiliki jangka waktu yang berbeda-beda pada setiap perusahaan. Berdasarkan penelitian-penelitian yang telah dilakukan terhadap teori siklus hidup perusahaan, diketahui bahwa setiap siklus hidup perusahaan memiliki karakteristik yang berbeda.

Siklus hidup perusahaan umumnya terbagi menjadi empat tahap, yakni startup, growth, maturity, dan decline. Namun terdapat juga beberapa penelitian yang membaginya kedalam tahap yang berbeda, seperti pada penelitian Miller dan Freiese (1984) yang dikutip dalam penelitian Razzaq (2007) membagi tahap siklus hidup perusahaan ke dalam lima fase, yaitu fase kelahiran (the birth phase), fase pertumbuhan (the growth phase), fase kematangan (the maturity phase), fase pengembangan ulang (the revival phase), dan yang terakhir adalah fase kemunduran (the decline phase). Pembagian fase siklus hidup perusahaan tersebut dibuat berdasarkan kecenderungan perbedaan pada beberapa faktor yang mempengaruhi perusahaan seperti kondisi perusahaan yang mencakup usia, ukuran, lingkungan eksternal, struktur, strategi, dan teknik pengambilan keputusan perusahaan."

Gambar 2.1 dibawah ini menggambarkan siklus hidup suatu perusahaan atau industri yang diungkapkan oleh Weston dan Brigham (2008) dikutip oleh Juiarti dan Limanjaya (2005 )dalam Erviana (2012): 


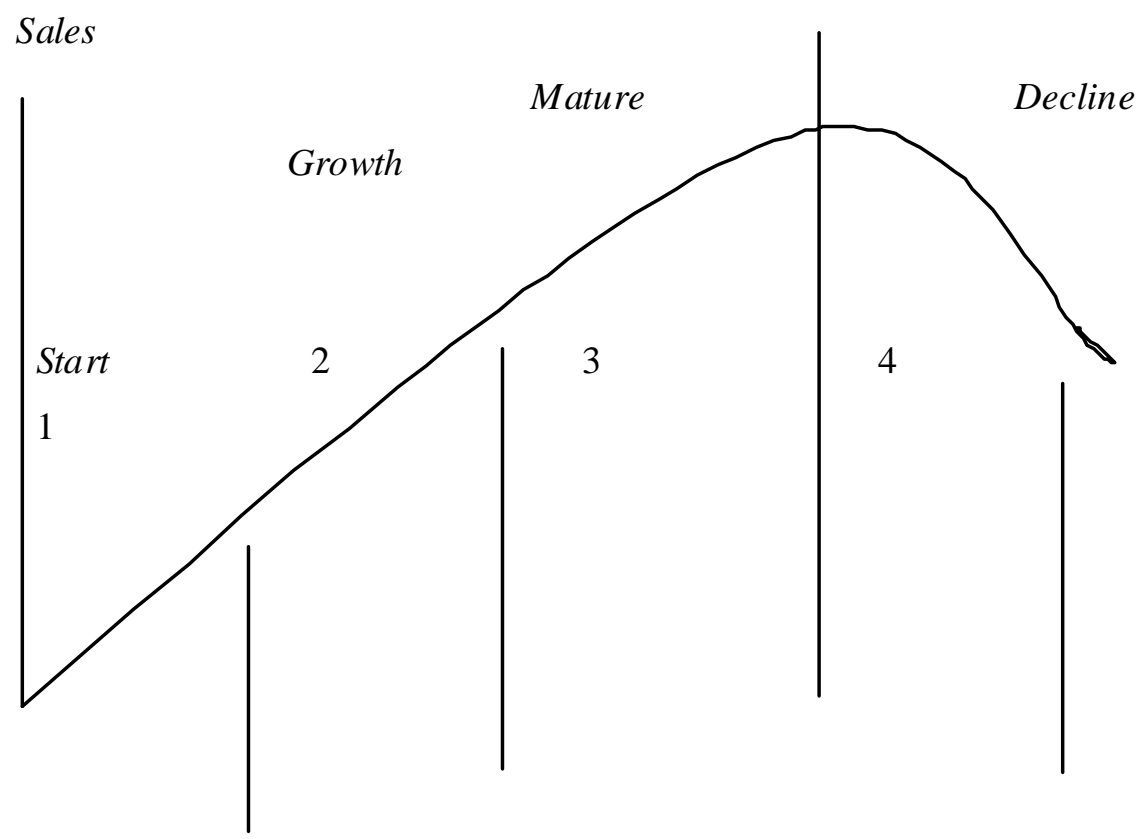

\section{Gambar 1. Life Cycle of a Typical Firm}

Sumber: Weston \& Brigham (1984:985) dikutip oleh Juniarti dan Limanjaya (2005) dalam Erviana (2012)

Setiap siklus hidup perusahaan berhubungan dengan besar laba dan arus kas yang dihasilkan oleh perusahaan. perbedaan tahap siklus hidup antar perusahaan juga harus dipertimbangkan pada saat menghitung nilai perusahaan. Hal ini disebut dengan konsep nilai perusahaan yang dikemukakan oleh Myers (1977) yang dikutip oleh Black (1998) dalam Erviana (2012:23). Konsep tersebut menyebutkan bahwa nilai perusahaan terdiri dari dua komponen, yaitu asset in place dan kesempatan tumbuh (growth opportunities). Proporsi kedua komponen tersebut berbeda antar tahap siklus hidup perusahaan yang menjadikannya karakteristik tersendiri bagi perusahaan yang berada dalam suatu tahapan siklus hidup.

Tahapan siklus hidup perusahaan juga memiliki hubungan dengan arus kas yang terdiri dari komponen arus kas dari aktivitas operasi, aktivitas investasi, dan juga aktivitas pendanaan. Hubungan antara tahapan siklus hidup perusahaan dengan arus kas perusahaan digambarkan melalui tabel 2.1. 
Tabel 1. Siklus Hidup Metode Arus Kas

\begin{tabular}{|c|c|c|c|c|}
\hline$\underbrace{\text { Life Cycle }}_{\text {Arus Kas }}$ & Start-up & Growth & Mature & Decline \\
\hline Arus Kas Operasional & $(-)$ & $(+)$ & $(+)$ & $(-)$ \\
\hline Arus Kas Investasi & $(-)$ & $(-)$ & $(-)$ & $(+)$ \\
\hline Arus Kas pendanaan & $(+)$ & $(+)$ & $(-)$ & $(+/-)$ \\
\hline
\end{tabular}

Sumber: Dickinson (2007) dalam Qodriyah (2012)

\section{Earning Management (Manajemen Laba)}

Menurut Chariri dan Ghozali (2001) dalam Shita (2011:29) Pengertian laba yang dianut oleh struktur akuntansi didefinisikan sebagai pembedaan antara pendapatan yang direalisasikan dari transaksi yang terjadi selama satu periode dengan biaya yang berkaitan dengan pendapatan tersebut."

Informasi laba sebagai salah satu elemen informasi akuntansi merupakan informasi yang berkualitas apabila menyajikan informasi yang relevan, netral, lengkap (komprehensif), tepat waktu dan memiliki daya banding serta daya uji. Informasi akuntansi harus dapat memenuhi kebutuhan semua pihak yang akan menggunakannya dan bebas dari ketergantungan dan keinginan pihak-pihak tertentu. Informasi laba juga harus komprehensif untuk mengungkapkan semua fakta baik transaksi maupun peristiwa yang dialami perusahaan selama satu periode.(Shita, 2011:30).

Untuk dapat menyajikan informasi dengan kriteria tersebut akuntansi menyediakan standar yang harus diikuti dan dipakai untuk menyusun laporan keuangan sehingga informasi yang dihasilkan mempunyai daya banding dan daya uji serta dapat dimengerti oleh pihak lain yang menggunakan laporan keuangan."Sulistyanto (2008) dalam (Shita, 2011:30).Dengan demikian, informasi laba memiliki nilai prediksi, nilai umpan balik, dan tersedia tepat waktu.

Perbedaan kepentingan pihak-pihak yang menggunakan laporan keuangan menyebabkan informasi yang dibutuhkan satu pihak dengan pihak lain menjadi berbeda. Untuk itu laporan keuangan harus dapat mengakomodasi dan memfasilitasi semua kebutuhan itu dengan baik. Earnings management yang dilakukan oleh manajer menyebabkan keputusan yang diambil oleh pemakai laporan keuangan menjadi keliru.

\section{Pengembangan Hipotesis Penelitian}

\section{Siklus Hidup Perusahaan Berpengaruh Negatif terhadap Earning Management}

Setiap siklus hidup perusahaan berhubungan dengan besar laba dan arus kas yang dihasilkan oleh perusahaan. perbedaan tahap siklus hidup antar perusahaan 
juga harus dipertimbangkan pada saat menghitung nilai perusahaan. Hal ini disebut dengan konsep nilai perusahaan yang dikemukakan oleh Myers (1977) yang dikutip oleh Black (1998) dalam Erviana (2012). Konsep tersebut menyebutkan bahwa nilai perusahaan terdiri dari dua komponen, yaitu asset in place dan kesempatan tumbuh (growth opportunities). Proporsi kedua komponen tersebut berbeda antar tahap siklus hidup perusahaan yang menjadikannya karakteristik tersendiri bagi perusahaan yang berada dalam suatu tahapan siklus hidup.

Hasil penelitian sebelumnya dilakukan oleh Shank dan Govindarajan (1992) dalam Ratna (2012:6) perusahaan pada tahap start-up dan growth menerapkan sistem pengendalian yang tidak ketat, dan pada tahap mature perusahaan menerapkan sistem pengendalian yang ketat, sehingga earning management (manajemen laba) lebih sering dilakukan pada tahap start-up dan growth dari pada tahap mature. Berdasarkan yang diuraikan tersebut, dirumuskan hipotesis sebagai berikut:

$\mathrm{H}_{1}$ : Siklus hidup perusahaan yang meningkat dari tahap start-up, growth, sampai dengan mature berpengaruh negatif terhadap earning management.

\section{Ukuran Perusahaan Berpengaruh Negatif terhadap Earning Management}

Ada pandangan yang menyebutkan bahwa ukuran perusahaan memiliki hubungan negatif dengan earning management. Penelitian Marrakchi (2001) dengan menggunakan data sampel perusahaan industri tahun 1996 menemukan bahwa Ukuran perusahaan memiliki hubungan negatif dengan earning management. Perusahaan yang lebih besar kurang memiliki dorongan untuk melakukan earning management dibandingkan perusahaan-perusahaan kecil, karena perusahaan besar dipandang lebih kritis oleh pemegang saham dan pihak luar. Perusahaan besar memiliki basis insvestor yang lebih besar, sehingga mendapat tekanan yang lebih kuat untuk menyajikan pelaporan keuangan yang kredibel.

Anggraini (2012) yang meneliti mengenai pengaruh siklus hidup perusahaan dan pengaruh ukuran perusahaan terhadap earning management. Hasil penelitian tersebut menjelaskan bahwa ukuran perusahaan memiliki pengaruh negatif secara signifikan terhadap earning management. Menurut Yan (2006 Shita (2011), ukuran perusahaan (ditunjukkan oleh aktiva dan penjualan) semakin meningkat seiring dengan perkembangan perusahaan melalui masing-masing tahap siklus perusahaan. Earning management lebih besar dilakukan oleh perusahaan yang kecil dibandingkan dengan perusahaan yang berukuran medium atau besar (Kim, et al., 2003) dalam Anggraini (2012).Berdasarkan yang diuraikan tersebut, dirumuskan hipotesis sebagai berikut: $\mathrm{H}_{2}$ : Ukuran perusahaan yang meningkat dari kecil, medium, sampai dengan besar berpengaruh negatif terhadap earning management. 


\section{METODE PENELITIAN}

\section{Jenis dan Sumber Data yang digunakan}

Teknik pengumpulan data dilakukan dengan sampling, yaitu pengumpulan data dengan mengambil sebagian dari elemen atau anggota populasi untuk diselidiki. (Hasan, 2001:18). Data yang digunakan dalam penelitian ini adalah data sekunder, Dalam penelitian ini data diakses melalui situs resmi BEI: www.idx.co.id,

\section{Populasi dan Sampel Penelitian}

Populasi yang digunakan dalam penelitian ini adalah perusahaan yang terdaftar di Bursa Efek Indonesia (BEI) dan memiliki laporan keuangan lengkap selama periode penelitian tahun 2013. Pemilihan sampel penelitian berdasarkan pada purposive sampling yakni teknik yang dilakukan berdasarkan kriteria yang disesuaikan dengan tujuan penelitian tertentu atau pertimbangan tertentu atau pertimbangan tertentu menurut (Indriantoro dan Supomo, 2002:131). Perusahaan publik yang terdaftar di BEI dan berikut karateristik pemilihan sampel yang digunakan untuk penelitian ini:

a. Perusahaan publik yang terdaftar di Bursa Efek Indonesia (BEI).

b. Perusahaan yang termasuk ke dalam kategori perusahaan pemanufakturan

c. Periode penelitian adalah tahun 2013. Perusahaan yang mempublikasikan laporan keuangan tahunan secara kosisten dari tahun 2012 sampai dengan 2013 yang telah di audit. Data tahun 2012 dibutuhkan untuk memperoleh data satu tahun sebelum tahun 2013.

d. Perusahaan yang memiliki data yang lengkap terkait dengan variabel-variabel yang digunakan dalam penelitian ini.

e. Menggunakan mata uang Rupiah dalam penyusunan laporan keuangan

\section{Definisi Operasional dan Pengukuran Variabel Penelitian}

Penelitian ini menguji tiga variabel, yaitu siklus hidup perusahaan, ukuran perusahaan dan earning management (manajemen laba). Siklus hidup perusahaan, ukuran perusahaan sebagai variabel dependen, earning management sebagai variabel independen.

\section{Variabel Dependen (Y)}

Penelitian ini menggunakan variabel dependen yaitu earning management. Diukur dengan menggunakan discretionary accruals sebagai proksi earning management yang diukur dengan model Jones yang dimodifikasi Dechow, et al., 1995), tahap-tahap penentuan discretionary accruals adalah seperti berikut: 
1. Menghitung total akrual dengan menggunakan pendekatan aliran kas (cash flow approach), yaitu:

Total akrual = laba perusahaan - aliran kas dari operasi

a. Menentukan koefisien dari regresi total akrual.

Akrual diskresioner merupakan perbedaan antara total akrual (TACC) dengan akrual nondiskresioner (nondiscretionary accrual- NDACC). Langkah awal untuk menentukan akrual nondiskresioner yaitu melakukan regresi sebagai berikut:

TACCt $/ \mathrm{TA}_{\mathrm{t}-1}=\mathrm{a}_{1}\left[1 / \mathrm{TA}_{\mathrm{t}-1}\right]+\mathrm{a}_{2}\left[\ddot{\mathrm{AREV}} \mathrm{t}_{\mathrm{t}} / \mathrm{TA}_{\mathrm{t}-1}\right]+\mathrm{a}_{3}\left[\mathrm{PPE}_{\mathrm{t}} / \mathrm{TA}_{\mathrm{t}-1}\right]+\varepsilon_{\mathrm{t}}$ Keterangan:

TACCt $=$ Total akrual pada tahun $\mathrm{t}$

$\mathrm{TA}_{\mathrm{t}-1}=$ total aktiva pada tahun $\mathrm{t}$

$\Delta \mathrm{REV}_{\mathrm{t}} \quad=$ pendapatan perusahaan pada tahun $\mathrm{t}-$ pendapatan tahun $\mathrm{t}-1$

$\Delta \mathrm{RECt}=$ piutang perusahaan $\mathrm{i}$ pada tahun $\mathrm{t}-$ piutang tahun $\mathrm{t}-1$

$\mathrm{PPE}_{\mathrm{t}} \quad=$ property, plant, and equipment pada tahun $\mathrm{t}$

$\mathrm{a}_{1}, \mathrm{a}_{2}, \mathrm{a}_{3}=$ koefisien regresi persamaan regresi OLS

$\varepsilon_{\mathrm{t}} \quad=$ error term tahun $\mathrm{t}$

b. Menentukan akrual nondiskresioner

Regresi yang dilakukan di (a) menghasilkan koefisien $\mathrm{a}_{1}, \mathrm{a}_{2}$, dan $\mathrm{a}_{3}$ Koefisien $\mathrm{a}_{1}, \mathrm{a}_{2}$, dan $\mathrm{a}_{3}$ tersebut kemudian digunakan untuk memprediksi akrual nondiskresioner melalui persamaam berikut:

$\mathrm{NDACC}=\mathrm{a}_{1}\left[1 / \mathrm{TA}_{\mathrm{t}-1}\right]+\mathrm{a}_{2}\left[\mathrm{AREV}_{\mathrm{t}}-\Delta \mathrm{RECt} / \mathrm{TA}_{\mathrm{t}-1}\right]+\mathrm{a}_{3}\left[\mathrm{PPE}_{\mathrm{t}} / \mathrm{TA}_{\mathrm{t}-1}\right]$

Keterangan:

NDACC = non discretionary accrual pada tahun $\mathrm{t}$

TAt-1 = total aktiva pada tahun $\mathrm{t}$

$\Delta \mathrm{REVt}=$ pendapatan perusahaan pada tahun $\mathrm{t}-$ pendapatan tahun $\mathrm{t}-1$

$\Delta \mathrm{RECt}=$ piutang perusahaan $\mathrm{i}$ pada tahun $\mathrm{t}-$ piutang tahun $\mathrm{t}-1$

PPEt = property, plant, and equipment pada tahun $\mathrm{t}$

a1, a2, a3 = koefisien regresi persamaan regresi OLS

c. Untuk menghitung nilai discretionary Accrual (DACC) yang merupakan ukuran earning management, setelah akrual nondiskresioner, kemudian akrual diskresioner bisa dihitung dengen mengurangkan total akrual (hasil perhitungan di (a)) dengan akrual nondiskresioner (hasil perhitungan di (b), diperoleh dari rumus berikut:

DACC $_{t}=\left(\right.$ TACC $\left./ \mathrm{TA}_{\mathrm{t}-1}\right)-\mathrm{NDACC}$

\section{Keterangan:}

$\mathrm{DAC}_{\mathrm{t}}=$ discretionary accrual pada tahun $\mathrm{t}$

TACC $\mathrm{t}=$ total akrual pada tahun $\mathrm{t}$

$\mathrm{TA}_{\mathrm{t}-1}=$ total aktiva pada tahun $\mathrm{t}$

NDACC $=$ non discretionary accrual pada tahun $\mathrm{t}$ 
Untuk tujuan estimasi, semua variabel diskalakan dengan total assets pada awal periode untuk menghilangkan pengaruh heteroskedasitas. Total aktiva digunakan oleh Jones (1991) karena ditemukan bahwa kuadrat residual dari ekspetasi yang tidak diskala dengan total aktiva berkorelasi kuat dengan kuadran aktiva tahun sebelumnya.

\section{Variabel Independen (X)}

Variabel bebas (independent variable) adalah variabel yang nilai-nilainya tidak bergantung pada variabel lainnya, biasanya disimbolkan dengan X. Variabel itu digunakan untuk meramalkan menerangkan nilai variabel yang lain.(Hasan, 2001:227). dalam penelitian ini variabel independen adalah:

\section{Siklus Hidup Perusahaan}

Siklus hidup perusahaan yang diukur dengan mengklasifikasikan siklus hidup ke dalam tiga tahap, yaitu start-up, growth, dan mature. Pengklasifikasian ke dalam tiga tahap berdasarkan penelitian Dickinson (2007) dan kemudian diterapkan oleh penelitian Diah (2009) yaitu menggunakan metode arus kas. Metode arus kas dianggap lebih sesuai dalam mengelompokkan perusahaan dalam siklus hidupnya. Berikut kriteria untuk mengklasifkasikan perusahaan:

\section{Tahap Life Cycle}

\begin{tabular}{llcc}
\hline A & Start-up & growth & mature \\
Arus kas & & & \\
Operasional & $(-)$ & $(+)$ & $(+)$ \\
Iinvestasi & $(-)$ & $(-)$ & $(-)$ \\
Pendanaan & $(+)$ & $(+)$ & $(-)$ \\
\hline
\end{tabular}

Sumber: Dickinson (2007) dalam Diah (2009)

Selanjutnya memasukkan tiap tahap perusahaan kedalam skala interval. Dalam tahap siklus hidup perusahaan, digunakan angka 1 untuk start-up, angka 2 untuk growth, dan angka 3 untuk mature.

\section{1) Ukuran Perusahaan}

Dalam penelitian ini variabel independen yang ke dua adalah ukuran perusahaan yang diukur dengan Total Aktiva kemudian, hasilnya di-log-kan.

Secara sitematis dapat diformulasikan sebagai berikut:

Size $=$ Ln $($ Total Aktiva $)$ 


\section{Metode Analisis Data}

Metode analisis yang digunakan yaitu dengan menggunakan model analisis regresi linear berganda yang menghubungkan beberapa variabel bebas dengan satu variabel terikat dengan menggunakan sofware SPSS 17.0 .

\section{Analisis Statistik Deskriptif}

Statistik deskriptif analisis data yang digunakan adalah dengan cara analisis kuantitatif yang bersifat deskriptif yang menjabarkan data yang diperoleh dengan menggunakan analisis regresi linier berganda untuk menggambarkan fenomena atau karakteristik dari data, yaitu dengan memberikan gambaran tentang pengaruh ukuran perusahaan dan ukuran perusahaan terhadap earning management (manajemen laba).

\section{Uji Asumsi Klasik}

Uji asumsi klasik bertujuan untuk mengetahui kelayakan penggunaan model regresi dalam penelitian ini. Uji asumsi klasik terdiri atas uji normalitas, uji multikolinearitas,, uji autokorelasi, dan uji heteroskedastisitas.

\section{Analisis Koefisien Determinasi}

Analisis koefisien determinari (R2) digunakan untuk mengetahui seberapa besar persentase variabel dependen dipengaruhi oleh variabel independen secara serentak terhadap variabel dependen (Priyatno, 2009:56).

\section{Pengujian Hipotesis}

Pengujian hipotesis dalam penelitian inidilakukan dengan analisis uji $\mathrm{F}$ untuk mengetahui pengaruh simultan variable size dan siklus hidup perusahaan terhadap manajemen laba. Sedangkan untuk mengetahu pengaruh partial digunakan uji t.

\section{HASIL DAN PEMBAHASAN PENELITIAN}

\section{Hasil Penelitian}

\section{Pemilihan Sampel Penelitian}

Berikut ini adalah sampel perusahaan manufaktur dengan kriteria-kriteria yang ditentukan sesuai dengan kebutuhan analisis data, Adapun kriteria dari sampel tersebut adalah Kriteria Sampel Penelitian. 
Tabel 1. Klasifikasi Perusahaan

\begin{tabular}{|c|c|c|}
\hline No & Klasifikasi Perusahaan & Jumlah \\
\hline 1 & $\begin{array}{l}\text { Perusahaan termasuk dalam industri manufaktur yang terdaftar di } \\
\text { bursa Efek Indonesia selama periode } 2010-2012\end{array}$ & 139 \\
\hline 2 & $\begin{array}{l}\text { Perusahaan yang tidak menggunakan mata uang Rupiah dalam } \\
\text { Laporan Keuangan }\end{array}$ & ( 14$)$ \\
\hline 3 & Perusahaan yang tidak memiliki kelengkapan data yang diperlukan & $(47)$ \\
\hline & Jumlah & 78 \\
\hline
\end{tabular}

Sumber: data diolah tahun 2014

\section{Jumlah Sampel berdasarkan Siklus Hidup Perusahaan (LC)}

Siklus hidup perusahaan pada penelitian ini menggunakan 3 tahap, yaitu Startup, growth, dan mature. Dengan menggunakan metode arus kas, maka dapat dilihat hasil pengklasifikasiannya pada tabel 2 berikut:

Tabel 2. Silklus Hidup Perusahaan

\begin{tabular}{cc}
\hline Silkus Hidup (LC) & Jumlah \\
\hline Start-up & 19 \\
Growth & 26 \\
Mature & 33 \\
\hline Total & 78 \\
\hline
\end{tabular}

Sumber: Data Olahan 2014

\section{Ukuran Perusahaan (Size)}

Dari seluruh total perusahaan di bagi dalam 3 tahap yaitu, menyusun urutan semua perusahaan sampel berdasarkan total aktivanya menetapkan sepertiga perusahaan sampel di urutan teratas sebagai perusahaan besar, sepertiga urutan terbawah sebagai perusahaan kecil, dan sepertiganya sebagai perusahaan sedang.

\section{Tabel 3. Kriteria Ukuran Perusahaan}

\begin{tabular}{cc}
\hline Ukuran Perusahaan (Size) & Jumlah \\
\hline Kecil & 26 \\
Sedang & 26 \\
Besar & 26 \\
\hline Total & 78 \\
\hline
\end{tabular}

Sumber: Data Olahan 2014 


\section{Statistik Deskriptif Data Penelitian}

Uji statistik deskriptif dilakukan untuk mengidentifikasi variabel-variabel yang akan diuji pada setiap hipotesis, bagaimana profil perusahaan dan distribusi variabelvariabel tersebut. Hasil analisis statistik deskriptif dengan bantuan komputer program SPSS for Windows Release 17 disajikan pada tabel berikut:

\section{Tabel 4. Statistik Deskriptif}

\begin{tabular}{lrrrrr}
\hline & N & Minimum & Maximum & \multicolumn{1}{c}{ Mean } & Std. Deviation \\
\hline MNJ_LB & 78 & .0239 & 1.8302 & .565132 & .2791283 \\
LC & 78 & 1 & 3 & 2.18 & .802 \\
SIZE & 78 & 24.8176 & 31.9889 & 28.037611 & 1.6249991 \\
Valid N (listwise) & 78 & & & & \\
\hline
\end{tabular}

Sumber: Data diperoleh menggunakan SPSS 17

Berdasarkan Tabel 4 diperoleh hasil sebagai berikut: Earning management (manajemen laba) memiliki rata-rata (mean) sebesar .565132 dengan standar deviasi .2791283, siklus hidup (life cycle) memiliki rata-rata (mean) sebesar 2.18 dengan standar deviasi .802, dan ukuran perusahaan (SIZE) memiliki rata-rata (mean) sebesar 28.037611 dengan standar deviasi 1.62499911.

\section{Uji Asumsi Klasik}

Pengujian asumsi klasik diperlukan untuk mendeteksi ada atau tidaknya penyimpangan asumsi klasik atas persamaan regresi berganda yang digunakan.

\section{1) Uji Normalitas}

Uji Normalitas bertujuan untuk menguji apakah dalam model regresi, variabel terikat dengan variabel bebas keduanya mempunyai distribusi normal atau tidak.

\section{Tabel 5. Tes Normalitas}

\begin{tabular}{llr}
\hline & & Unstandardized Residual \\
\hline $\mathrm{N}$ & & 78 \\
Normal Parameters ${ }^{\mathrm{a}, \mathrm{b}}$ & Mean & .0000000 \\
& Std. Deviation & .26215445 \\
Most Extreme Differences & Absolute & .072 \\
& Positive & .072 \\
& Negative & -.067 \\
Kolmogorov-Smirnov Z & & .632 \\
Asymp. Sig. (2-tailed) & & .820 \\
\hline
\end{tabular}

a. Test distribution is Normal.

b. Calculated from data.

Sumber: Data diperoleh menggunakan SPSS 17

El-Muhasaba, Vol. 5, No 1, Januari 2014 
Dari Tabel 5 di atas dapat diketahui pengujian terhadap normalitas data dengan menggunakan uji Kolmogrov-Smirnov menunjukkan nilai signifikan karena Asymp. Sig. (2-tailed) lebih besar dari 0,05 yaitu 0,821 hal ini berarti data terdistribusi dengan normal.

\section{2) Uji Multikolinearitas}

Uji Multikolinearitas adalah bertujuan untuk menguji apakah di dalam model regresi ditemukan adanya korelasi antar variabel bebas. Multikolinearitas terjadi bila nilai VIF $>10$ dan jika tolerance $<0,1$. Dari hasil pengolahan data statistik diperoleh tabel pengujian Multikolinearitas sebagai berikut:

Tabel 6. Uji Multikolinearitas

\begin{tabular}{|c|c|c|c|c|c|c|}
\hline \multirow[t]{2}{*}{ Model } & & \multicolumn{2}{|c|}{$\begin{array}{l}\text { Unstandardized } \\
\text { Coefficients }\end{array}$} & \multirow{2}{*}{$\begin{array}{c}\begin{array}{c}\text { Standardized } \\
\text { Coefficients }\end{array} \\
\text { Beta } \\
\end{array}$} & \multicolumn{2}{|c|}{ Collinearity Statistics } \\
\hline & & B & Std. Error & & Tolerance & VIF \\
\hline \multirow{3}{*}{1} & (Constant) & -.101 & .528 & & & \\
\hline & $\mathrm{LC}$ & .107 & .039 & .307 & 919 & 1.088 \\
\hline & SIZE & .015 & .019 & .090 & .919 & 1.088 \\
\hline
\end{tabular}

a. Dependent Variable: MNJ_LB

Sumber: Data diperoleh menggunakan SPSS 17

Berdasarkan tabel diatas dapat diketahui bahwa nilai VIF untuk masing-masing variabel adalah 1.088 untuk variabel ukuran perusahaan (SIZE) dan 1.088 untuk variabel siklus hidup (LC), karena semua nilai VIF variabel bebasnya kurang dari 10 maka dapat disimpulkan bahwa dalam model regresi tidak menunjukkan gejala multikolinearitas.

\section{3) Uji Autokolerasi}

Uji Autokolerasi bertujuan untuk menguji apakah dalam model regresi terjadi korelasi dari residual untuk pengamat satu dengan pengamat lain yang disusun menurut ketentuan waktu. 
Tabel 7. Uji Autokolerasi

\begin{tabular}{rrrrrr}
\hline Model & R & R Square & $\begin{array}{l}\text { Adjusted } \\
\text { R Square }\end{array}$ & $\begin{array}{l}\text { Std. Error of } \\
\text { the Estimate }\end{array}$ & $\begin{array}{l}\text { Durbin- } \\
\text { Watson }\end{array}$ \\
\hline 1 & $.343^{\mathrm{a}}$ &, 118 &, 094 &, 2656269 & 1,669 \\
\hline
\end{tabular}

a. Predictors: (Constant), SIZE, LC

b. Dependent Variable: MNJ_LB

Sumber: Data diperoleh menggunakan SPSS 17

Tabel 7. Pengujian Autokorelasi

\begin{tabular}{|c|c|c|c|c|}
\hline $\begin{array}{c}\text { Ada auto } \\
\text { korelasi } \\
\text { positif }\end{array}$ & $\begin{array}{c}\text { Daerah } \\
\text { keragu-raguan }\end{array}$ & $\begin{array}{c}\text { Tidak ada } \\
\text { autokorelasi }\end{array}$ & $\begin{array}{c}\text { Daerah } \\
\text { keragu-raguan }\end{array}$ & $\begin{array}{c}\text { Ada } \\
\text { autokorelasi } \\
\text { negatif }\end{array}$ \\
\hline \multicolumn{5}{|c|}{$\vec{w} \mathrm{du}$} \\
\hline 0 & 1,669 & & 2,315 & \\
\hline
\end{tabular}

Berdasarkan Tabel 7 hasil pengujian dapat diketahui bahwa uji autokorelasi dapat diketahui bahwa nilai Durbin-Watson adalah 1.669, dan berada pada daerah $\mathrm{dl}<\mathrm{DW}>\mathrm{du}$, maka dapat disimpulkan tidak ada keputusan dalam model regresi (ragu-ragu). Dengan demikian model persamaan regresi yang diperoleh masih bisa digunakan untuk menarik kesimpulan (bisa dianggap tidak ada gangguan autokorelasi) (Prakosa, 2003:11).

\section{4) Uji Heteroskedastisitas}

Uji Heteroskedastisitas bertujuan untuk menguji apakah dalam model regresi terjadi ketidaksamaan variance dan residual satu pengamatan ke pengamatan lain. Jika ada pola yang tertentu, maka telah terjadi heteroskedastisitas. Jika tidak ada pola yang jelas, serta titik-titik menyebar di atas dan di bawah angka 0 pada sumbu Y, maka tidak terjadi Heteroskedastisitas. 


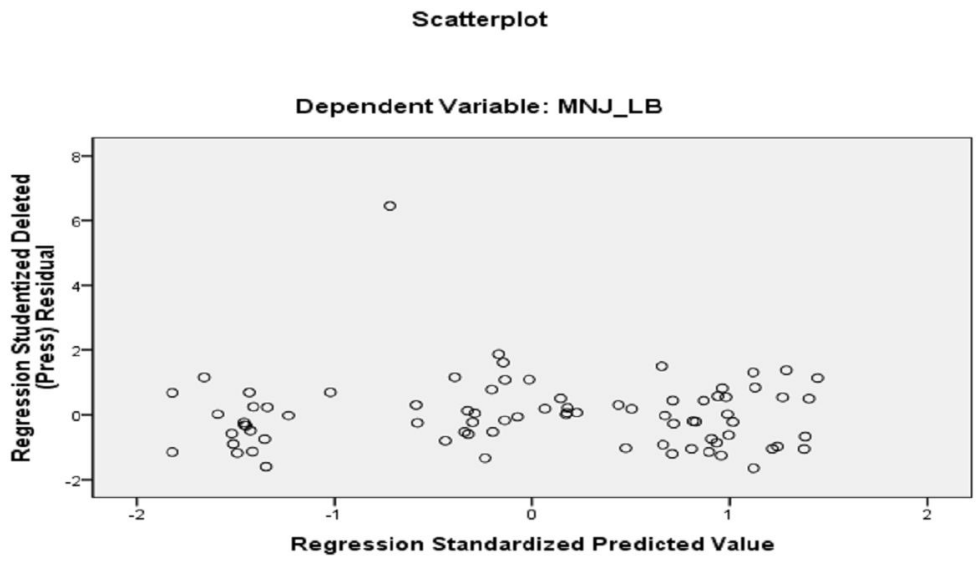

\section{Gambar 4. Uji Heteroskedastisitas}

Sumber: Data diperoleh menggunakan SPSS 17

Berdasarkan gambar 4 di atas, dapat disimpulkan bahwa model regres dalam penelitian ini tidak terjadi Heteroskedastisitas. Karena titik-titiknya menyebar di atas dan dibawah angka 0 pada sumbu Y.

\section{Hasil Analisis Regresi Linear Berganda Pengujian koefisien Determinasi}

Tabel 9. Koefisien Determinasi

Model Summary

Model

$\mathbf{R}$

R Square

Adjusted R Square

Std. Error of the

Estimate

$1 \quad .343^{\mathrm{a}}$ , 118

, 094

,2656269

a. Predictors: (Constant), SIZE, LC

b. Dependent Variable: MNJ_LB

Sumber: Data diperoleh menggunakan SPSS 17

Dari pengolahan regresi berganda diketahui koefisien determinasi yang dilihat dari R Square adalah 0,118 atau 11,8\%. Hal ini menunjukkan bahwa prosentase sumbangan pengaruh variabel independen yang terdiri dari ukuran perusahaan dan siklus hidup terhadap variabel dependen yaitu earning management sebesar 11,8\%. Atau variasi variabel yang digunakan dalam model, mampu menjelaskan sebesar $11,8 \%$ variabel independen. Sedangkan sisanya $88,2 \%$ dipengaruhi oleh variabel lain. 


\section{Pengujian Hipotesis}

\section{1) Uji F (Uji Simultan)}

Untuk mengetahui apakah terdapat pengaruh antara variabel ukuran perusahaan dan siklus hidup secara bersama-sama (simultan) terhadap variabel earning management pada perusahaan manufaktur yang terdaftar di Bursa Efek Indonesia (BEI), dilakukan uji F (Uji Simultan). Untuk lebih jelasnya hasil perhitungan dapat dilihat pada tabel berikut:

Tabel 10. Hasil Uji F (Uji Simultan)

ANOVA $^{b}$

\begin{tabular}{llrrrrr}
\hline Model & & Sum of Squares & df & Mean Square & F & Sig. \\
\hline 1 & Regression & .707 & 2 & .354 & 5.013 & $.009^{\mathrm{a}}$ \\
& Residual & 5.292 & 75 & .071 & & \\
\hline & Total & 5.999 & 77 & & & \\
\hline \multicolumn{2}{l}{} \\
\hline
\end{tabular}

a. Predictors: (Constant), SIZE, LC

b. Dependent Variable: MNJ_LB

Sumber: Data diperoleh menggunakan SPSS 17

Hasil uji hipotesis dapat dilihat pada Tabel 10, nilai F yang diperoleh sebesar 5.013 dengan tingkat signifikan sebesar 0.009 yang berarti model regresi ini layak untuk digunakan karena tingkat signifikansi lebih kecil dari 0.05 di mana Ha diterima. artinya ada pengaruh signifikan antara ukuran perusahaan dan siklus hidup perusahaan secara bersama-sama terhadap earning management.

\section{2) Uji t (Uji Parsial)}

Uji t (Uji Parsial) digunakan untuk mengetahui pengaruh masing-masing variabel independen, yaitu ukuran perusahaan dan siklus hidup terhadap variabel earning management, yaitu perubahan harga saham pada perusahaan manufaktur yang terdaftar di Bursa Efek Indonesia (BEI) tahun 2013. Pengambilan keputusan didasarkan pada probabilitas signifikan 0,05 (5\%). 
Tabel 11. Hasil Uji t (Uji Parsial)

Coefficients $s^{\mathrm{a}}$

\begin{tabular}{ccccccc}
\hline \multirow{2}{*}{ Model } & \multicolumn{2}{c}{$\begin{array}{c}\text { Unstandardized } \\
\text { Coefficients }\end{array}$} & $\begin{array}{c}\text { Standardized } \\
\text { Coefficients }\end{array}$ & T & \multirow{2}{*}{ Sig. } \\
\cline { 2 - 4 } & B & Std. Error & Beta & & \\
\hline \multirow{2}{*}{1} & (Constant) &,- 101 &, 528 & &,- 192 &, 849 \\
& LC &, 107 &, 039 &, 307 & 2,713 &, 008 \\
& SIZE &, 015 &, 019 &, 090 &, 796 &, 429 \\
\hline
\end{tabular}

a. Dependent Variable: MNJ_LB

Sumber: Data diperoleh menggunakan SPSS 17

Berdasarkan Tabel 11 di atas menghasilkan model regresi berikut ini: $\mathrm{Y}=0.671-0.012 \mathrm{SIZE}+0.091 \mathrm{LC}$

Uji signifikansi masing-masing variabel diuraikan sebagai berikut:

(1) Siklus Hidup Perusahaan ( $L C$ )

Berdasarkan hasil perhitungan dengan menggunakan program spss 17.00 for windows seperti terlihat pada Tabel 4.11 tersebut, diperoleh $t_{\text {hitung }}$ sebesar 2,713, $\mathrm{t}_{\text {tabel }}$ sebesar 1,665 dengan $\mathrm{n}=78$ dan $\mathrm{df}=\mathrm{n}-\mathrm{k}-1$ atau 78-3-1=74, dengan tingkat signifikansi $0,008 £ 0,05$. Maka dapat disimpulkan bahwa $t_{\text {hitung }}(2,713)$ $>\mathrm{t}_{\text {tabel }}(1,665)$ jadi hipotesis $\mathrm{Ha}_{1}$ ditolak, artinya secara parsial ada pengaruh positif dan signifikan siklus hidup dengan dilakukannya praktik earning management.

(2) Ukuran Perusahaan (Size)

Variabel ukuran perusahaan memiliki nilai t hitung sebesar 0,796, dapat disimpulkan $\mathrm{t}_{\text {hitung }}(0.796)<\mathrm{t}_{\text {tabel }}(1,665)$ dengan tingkat signifikansi 0,429 yang lebih besar dari 0,05 jadi hipotesis $\mathrm{Ha}_{2}$ ditolak, artinya secara parsial tidak ada pengaruh signifikan setiap tahapan ukuran perusahaan dengan dilakukannya praktik earning management.

\section{PEMBAHASAN}

Berdasarkan hasil pengujian variabel penelitian secara simultan terlihat bahwa antara variabel indepeden yaitu siklus hidup dan ukuran perusahaan dengan variabel dependen earning management mempunyai pengaruh yang signifikan ditunjukkan dengan tingkat signifikansi $0.009<$ dari 0,05 .

\section{Pengaruh Siklus Hidup terhadap Earning Management}

Berdasarkan hasil pengujian parsial pada Tabel 11 menunjukkan bahwa variabel Siklus hidup dengan nilai $t_{\text {hitung }}$ bahwa $t_{\text {hitung }}(2,713)>t_{\text {tabel }}(1,665)$ dengan tingkat 
signifikansi $0,008 \leq 0,05$ jadi hipotesis $\mathrm{Ha}_{1}$ ditolak, artinya secara parsial ada pengaruh positif Signifikan siklus hidup terhadap earning management. Perbedaan hasil penelitian ini dengan penelitian sebelumnya yaitu Anggraini (2012) yaitu tidak terdapat pengaruh signifikan siklus hidup terhadap praktik earning management dikarenakan adanya perbedaan dalam cara pengukuran variabel. Hasil penelitian ini sesuai dengan hasil penelitian Hastuti (2006) yang menyimpulkan bahwa terdapat earning management dalam perusahaan-perusahaan yang berada pada tahap siklus hidup Sri Hastuti (2006) melakukan penelitian mengenai apakah terdapat earning management dalam perusahaan-perusahaan yang berada pada tahap growth, mature, dan stagnant. Penelitian tersebut menunjukan bahwa earning management terdapat pada tahapan siklus hidup, perusahaan yang berada pada tahap stagnant lebih kecil secara signifikan daripada perusahaan yang berada pada tahap mature. Namun penelitian tersebut tidak dapat membuktikan bahwa earning management pada perusahaan yang mature lebih kecil secara signifikan dibandingkan dengan perusahaan yang growth sehingga disimpulkan earning management terjadi disetiap tahap siklus hidup dan pengaruhnya terhadap earning management positif. Earning management yang lebih kecil dilakukan pada perusahaan yang berada pada tahap stagnant dibandingkan dengan perusahaan yang berada pada tahap mature juga didukung oleh hasil penelitian Teoh, et al. (1998) dalam Anggraini (2012:6) yang menyatakan bahwa pada saat setelah IPO (pada tahap decline), earning management (digambarkan oleh discretionary accrual) menurun dan lebih kecil dibandingkan pada saat ooffering (pada tahap mature).

\section{Pengaruh Ukuran Perusahaan terhadap Earning Management}

Sementara itu berdasarkan hasil uji parsial (uji t) ukuran perusahaan menunjukkan tidak ada pengaruh signifikan terhadap earning management di perusahaan manufaktur yang terdaftar di Bursa Efek Indonesia hal ini dapat dibuktikan dari nilai $\mathrm{t}_{\text {hitung }}(0.796)<\mathrm{t}_{\text {tabel }}(1,665)$ dengan tingkat signifikansi 0,429 yang lebih besar dari 0,05 jadi hipotesis nol tidak dapat ditolak, artinya ha2 ditolak, jadi secara parsial tidak ada pengaruh ukuran perusahaan dengan dilakukannya earning management.

Hasil penelitian ini sesuai dengan hasil penelitian Nasution dan Setiawan (2007), Penelitian yang menganalisis pengaruh dari mekanisme corporate governance yaitu komposisi dewan komisaris, ukuran dewan komisaris, keberadaan komite audit, ukuran perusahaan terhadap earning management. Dengan menggunakan metode analisis regresi berganda, mereka menemukan bahwa ukuran perusahaan tidak berpengaruh terhadap earning management. Penelitian ini juga sesuai dengan hasil penelitian yang dilakukan oleh Marihot dan Doddy (2007), Jin dan Machfoeds (1998), Salno dan Baridwan (2002), serta Nasser dan Herlina (2003) yang menemukan bahwa ukuran perusahaan tidak berpengaruh pada praktik earning management. 
Hasil penelitian ini bertentangan dengan hasil penelitian yang dilakukan oleh Veronika dan Utama (2005), melakukan penelitian mengenai pengaruh struktur kepemilikan, ukuran perusahaan, dan praktik corporate governance terhadap besarnya pengelolaan laba pada 144 perusahaan yang terdaftar di BEJ dengan hasil penelitian bahwa ukuran perusahaan pengaruh signifikan terhadap besarnya pengelolaan laba. Halim Meiden dan Tobing (2005) Menemukan bahwa ukuran Perusahaan mempunyai pengaruh signifikan terhadap earning management. Dan Anggraini (2012) yang meneliti mengenai pengaruh ukuran perusahaan terhadap earning management, hasil penelitian tersebut menjelaskan bahwa ukuran perusahaan memiliki pengaruh negatif secara signifikan terhadap earning management.

Ukuran perusahaan tidak berpengaruh terhadap earning management hal ini dikarenakan setiap ukuran perusahaan dari yang kecil, sedang sampai ukuran perusahaan yang besar memiliki kecenderungan melakukan earning management, untuk menghindari pelaporan penurunan laba (earning decreases), hal ini didukung oleh hasil penelitian yang dilakukan oleh Handayani dan Rachadi (2009) yang meneliti pengaruh ukuran perusahaan terhadap earning management, dengan hasil penelitian bahwa setiap ukuran perusahaan malakukan earning management.

\section{SIMPULAN}

\section{Simpulan}

Berdasarkan hasil penelitian dan pembahasan yang telah dikemukakan sebelumnya maka simpulan dalam penelitian ini adalah:

Siklus hidup perusahaan, hasil pengujian parsial (uji t) menunjukkan bahwa variabel siklus hidup dengan nilai $\mathrm{t}_{\text {hitung }}$ sebesar 2,713 , $\mathrm{t}_{\text {tabel }}$ sebesar 1,665 dengan $\mathrm{n}=78$ dan $\mathrm{df}=\mathrm{n}-\mathrm{k}-1$ atau 78-3-1=74, dengan tingkat signifikansi 0,008 $\leq 0,05$. Maka dapat disimpulkan bahwa $t_{\text {hitung }}(2,713)>t_{\text {tabel }}(1,665)$ jadi hipotesis $\mathrm{Ha}_{1}$ ditolak, artinya secara parsial ada pengaruh positif dan signifikan siklus hidup dengan dilakukannya praktik earning management.

Ukuran perusahaan, berdasarkan hasil uji parsial (uji t) menunjukan hipotesis $\mathrm{Ha}_{2}$ ditolak, variabel ukuran perusahaan tidak ada pengaruh signifikan terhadap earning management dengan nilai $t_{\text {hitung }}$ sebesar 0,796 , dapat disimpulkan $t_{\text {hitung }}$ $(0.796)<\mathrm{t}_{\text {tabel }}(1,665)$ dengan tingkat signifikansi 0,429 yang lebih besar dari 0,05.

\section{Keterbatasan}

Penelitian ini menggunakan perusahaan manufaktur sebagai sampel sehingga hasil penelitian ini tidak dapat digeneralisasikan pada jenis perusahaan lain seperti perbankan, transportasi, dan telekomunikasi.

Rentang waktu yang digunakan dalam penelitian ini, yaitu selama satu tahun, yang terlalu singkat. 
Penelitian ini hanya meneliti siklus hidup dan ukuran perusahaan yang mempengaruhi earning management.

Penelitian ini hanya menggunakan medote accrual dalam mengukur earning management.

\section{Saran}

Saran yang diberikan berkaitan dengan hasil penelitian ini sebagai berikut:

Hasil penelitian ini diharapkan dapat memberi masukan bagi investor dalam melakukan investasi saham dengan melihat siklus hidup dan ukuran perusahaan.

Untuk penelitian selanjutnya bisa meneliti seluruh perusahaan yang terdaftar di Bursa Efek Indonesia tidak hanya perusahaan manufaktur saja, menambah jangka waktu penelitian, supaya menjelaskan lebih akurat.

Selain itu peneliti selanjutnya diharapkan menambah faktor pengaruh earning management lainnya yang tidak dimasukkan dalam penelitian ini berpengaruh terhadap praktik earning management sebagai variabel independen, karena sangat dimungkinkan faktor lain seperti good corporate governance, Ukuran dewan komisaris, proporsi dewan komisaris independen, komite audit, reputasi Auditor, profitabilitas, leverage, asimetri informasi, kinerja masa kini, kinerja masa depan return kumulatif, current ratio, sektor industri dan lain-lain.

Serta peneliti selanjutnya dapat mengukur earning management dengan menggunakan metode laba riil tidak hanya dengan metode accrual saja.

\section{DAFTAR PUSTAKA}

Anggraini, A.R. 2012. "Pengaruh Siklus Hidup dan Ukuran Perusahaan terhadap Manajemen Laba". Skripsi Universitas Brawijaya Malang.

Diah, U.P. 2009. Relevansi Nilai Laba dan Aruskas: Studi Siklus Hidup Perusahaan (Metode Cash Flow Patterns). Skripsi, Universitas Sebelas Maret. Surakarta.

Erviana, W. 2012. "Analisis Hubungan Tahap Siklus Hidup dan Ukuran Perusahaan Terhadap Pembayaran PPh Perusahaan”. Skripsi Universitas Indonesia.

Firdaus. 2009. "Pengaruh Tahapan Siklus Hidup terhadap Perusahaan terhadap Pembayaran PPh”. Depok: Dept Akuntansi FEUI. Skripsi universitas Indonesia.

Hasan, M. I. 2001. Pokok-pokok Statistik 2. Jakarta: Bumi Aksara.

Hastuti, S. 2006. "Perbedaan Perilaku Earnings Manajement Berdasarkan pada Life Cycle Perusahaan”. Tesis, Universitas Gadjah Mada, Yogyakarta.

Indriatoro, N., dan Bambang, S. 2000. Metodelogi Penelitian Bisnis dan Manajemen. Edisi Pertama. Yogyakarta: BPFE Yogyakarta.

Prakosa, K.B. 2003. ”Analisis Pengaruh Kebijakan Tax Holiday terhadap Perkembangan Penanaman Modal'. Jurnal Ekonomi Pembangunan Vol. 8 No.1, Juni 2003.

Priyatno, D. 2008. Mandiri Belajar SPSS. Edisi Pertama. Yogyakarta: Medikom.

Priyatno, D. 2009. SPSS untuk Analisis Korelasi, Regresi, dan Multivariate. Yogyakarta: Gava Media. 
Qodriyah, R.D.L. 2012. Laba atau Arus Kas Sebagai Parameter Kinerja Perusahaan Berdasarkan Siklus Hidup Perusahaan. Jurnal akuntansi dan Ekonomi Bisnis Vol No.1 Tahun 2012.

Riahi, A., dan Belkaoui. 2007. Accounting Theory. Edisi kelima. Jakarta: Salemba Empat.

Setiawan, I.K. 2011. "Pengaruh Struktur Aktiva, Ukuran Perusahaan, Profitabilitas dan Risiko Bisnis terhadap Struktur Modal Perusahaan Industri Makanan dan Minuman yang Go Publik di Bursa Efek Indonesia”. Skripsi Universitas Tadulako Palu.

Shita, I.G.A.P. 2011. Analisa Faktor-Faktor yang Berpengaruh terhadap Manajemen Laba. Skripsi, Universitas Diponegoro. Semarang.

Siregar, Silvia Veronika N.P., dan Siddharta, U. 2005. Pengaruh Stuktur Kepemilikan, ukuran perusahaan dan Praktik Corporate Governance terhadap pengelolaan Laba (Earnings Manajement). Jurnal Simposium Nasional Akuntansi VIII.

Soepratikno dan Hartono. 2005. Pengaruh Atribut Perusahaan terhadap Relevansi Laba dan Arus Kas. Jurnal Akuntansi dan Keuangan Vol.8 No.3;211-234.

Susanto, S., dan Ekawati, E. 2006." Relevansi Nilai Informasi Laba dan Aliran Kas Terhadap Harga Saham dalam Kaitannya dengan Siklus Hidup”. Simposium Akuntansi 9 Padang.

Sutarno, B. 2002. ”Analisi Laba dan Arus Kas Terhadap Siklus Hidup Perusahaan Diukur dengan Nilai Pasar Ekuitas". Tesis Universitas Diponegoro Semarang.

- 2012. Pernyataan Standar Akuntansi Keuangan (PSAK) NO.1: Penyajian Laporan Keuangan. Jakarta: IAI.

www.idx.co.id 